2018-08

\title{
Microplastics in different tissues of fish and prawn from the Musa Estuary, Persian Gulf.
}

\author{
Abbasi, S
}

http://hdl.handle.net/10026.1/11614

10.1016/j.chemosphere.2018.04.076

Chemosphere

Elsevier

All content in PEARL is protected by copyright law. Author manuscripts are made available in accordance with publisher policies. Please cite only the published version using the details provided on the item record or document. In the absence of an open licence (e.g. Creative Commons), permissions for further reuse of content should be sought from the publisher or author. 
1 Microplastics in different tissues of fish and prawn from the Musa Estuary,

\section{Persian Gulf}

4 Sajjad Abbasi $^{\text {a, *, Naghmeh Soltani }}{ }^{\text {a }}$, Behnam Keshavarzi ${ }^{\text {a }}$, Farid Moore ${ }^{\text {a }}$, Andrew Turner ${ }^{\text {b }}$,

5 Mina Hassanaghaei ${ }^{\text {a }}$

6

$7 \quad{ }^{a}$ Department of Earth Sciences, College of Sciences, Shiraz University, Shiraz, 71454, Iran.

$8 \quad{ }^{\mathrm{b}}$ School of Earth, Ocean and Environmental Sciences, Plymouth University, PL4 8AA, UK

$9 *$ Corresponding author. Department of Earth Sciences, College of Science, Shiraz University, 1071454 Shiraz, Iran.

11 E-mail address: Sajjad.Abbasi@ shirazu.ac.ir

12 


\section{Highlights}

- Microplastics (MPs) have been determined in tissues of fish and crustaceans from the Musa estuary and Persian Gulf

- 828 MPs of mainly a fibrous nature were detected in all tissues and species examined

- Mean abundance ranged from 7.8 in tiger prawn to 21.8 in bartail flathead

- The means by which MPs enter non-digestive tissues is unclear

- The occurrence of MPs in seafood for human consumption is cause for concern (1)

\section{Abstract}

Commercially-important species of fish and a crustacean from four sites in the Musa estuary and a site in the Persian Gulf have been analysed for the presence and location of microplastics (MPs). A total of 828 MPs were detected in the guts (gastrointestinal tracts), skin, muscle, gills and liver of demersal and pelagic fish (Platycephalus indicus, Saurida tumbil, Sillago sihama, Cynoglossus abbreviatus) from all five sites and in the exoskeleton and muscle of the tiger prawn, Penaeus semisulcatus, from three sites. On an individual basis, MPs were most abundant in $P$. indicus $($ mean $=21.8)$ and least frequently encountered in $P$. semisulcatus $($ mean $=7.8)$, but when normalized on a mass basis, MPs ranged from $0.16 \mathrm{~g}^{-1}$ for $C$. abbreviatus to $1.5 \mathrm{~g}^{-1}$ for $P$. semisulcatus. Microscopic analyses (polarized light, fluorescence, SEM/EDS) revealed that MPs were mainly fibrous fragments (with a few angular fragments) of various colour and size $(<100$ $\mu \mathrm{m}$ to $>1000 \mu \mathrm{m}$ ) and with strong $\mathrm{C}$ and $\mathrm{O}$ signatures. Additional particles detected that were distinctly different in colour, morphology, brittleness and elemental composition (part-metallic, and containing $\mathrm{Cu}$ ) were suspected of being fragments of antifouling paint. The means of entry of 
MPs into tissues not involved in digestion are unclear but could be related to translocation or

37 adherence. Regardless of the mode of accumulation, the presence of MPs in heavily fished species of fish and crustacean raises concerns about the potential transfer of synthetic materials into 39 humans.

Keywords: Microplastics; fish; prawns; accumulation; microscopy; Persian Gulf

42

\section{Introduction}

While the effects of chemical pollutants on marine ecosystems have been studied for many 46 decades, the pervasiveness and impacts of litter on marine life have been recognized more recently

47 (Auta et al., 2017; do Sul and Costa, 2014). Plastics, as identifiable primary objects or secondary 48 fragmented pieces, comprise the largest pool of litter on both a mass and number basis and enter 49 the oceans via rivers, sewage discharge, land run-off, and spillages and discharges from ships at 50 sea (Moore, 2008; Andrady, 2011; Barnes et al., 2009; Gregory and Andrady, 2003). Given the 51 expected future demand and discharges of plastic, coupled with the resistance of synthetic 52 polymers to environmental degradation, it is clear that the marine plastic inventory will continue 53 to increase beyond at least the next decade (Jambeck et al., 2015).

54

55 Of particular concern with respect to both the direct impacts on marine life and transfer through 56 the foodchain are readily ingestible microplastics (MPs), or synthetic particles ranging from a few 57 micrometers to five millimeters in any dimension (Alomar et al., 2016; Turner, 2017; Abbasi et 
al., 2017). Primary MPs include abrasive micro-beads in face scrubber cosmetics and toothpaste,

59 synthetic fibres and pre-production resin pellets, while secondary MPs are generated in situ by the mechanical and oxidative breakdown of larger plastics (Hidago-Ruz et al., 2012). As well as the

61 inherent composition of the polymer and the presence of any additives, the chemistry of MPs may

62 be modified by the adsorption of toxic substances from ambient sea water to the hydrophobic 63 plastic surface (e.g. organic pollutants; Teuten et al. 2007; Ziccardi et al. 2016) or to more 64 hydrophilic, hydrogenous or biogenic phases coating the surface (e.g. heavy metals; Ashton et al., 65 2010; Holmes et al., 2014).

66

67 A wide range of marine organisms, including bivalves, zooplankton, fish, invertebrates, birds and 68 cetaceans, incidentally take up MPs from sediment or the water column because they mistake them 69 for food (Cole et al. 2013; Lusher et al. 2015; Ferreira et al. 2016). Ingesting MPs of no nutritional 70 value may induce physical and chemical toxicity, block or damage the digestive tract, or decrease 71 individual fitness, ultimately resulting in death (Wright et al., 2013; Luís et al. 2015; De Sá and 72 Guilhermino 2015). Moreover, MPs of tens of micrometers in dimension have the propensity to 73 translocate from the gut to the circulatory system in many organisms where they may reside for 74 relatively long periods of time (Browne et al., 2008; van Cauwenberghe et al., 2015; Collard et al., 75 2017). While the effects of translocated MPs on chronic animal health are unknown, their presence 76 is of particular concern because consumption of contaminated food, including fish and shellfish, 77 may act as a vehicle for the ingestion and translocation of MPs in humans (Li et al., 2015; Rist et 78 al., 2018). 
80 The Musa is one of the biggest estuaries in the northern Persian Gulf and is the most important

81 fishery resource for people in the cities of Mashahr (population 150,000), Sarbandar (75,000) and

82 Hendijan (50,000). While the coast of the estuary is flanked by agricultural land, there are also

83 various industrial plants and extensive docks that support the petrochemical and shipping

84 industries and municipal and industrial sewage from the catchment is poorly treated (Hosseini et

85 al., 2013; Rastegari Mehr et al., 2016). Given these conflicting uses of the estuary, the aim of the

86 present study was to determine whether MPs are accumulating in different organs of five abundant

87 and commercially valuable species of fish and crustacean that are heavily consumed by local

88 people. Specifically, we target the skin, gastrointestinal tract, liver, muscle and gills of two

89 demersal fish, the bartail flathead (Platycephalus indicus) and greater lizardfish (Saurida tumbil),

90 one pelagic fish, the northern whiting (Sillago sihama), and one mesopelagic species fish, the

91 tongue sole (Cynoglossus abbreviatus), and the skin and muscle of the tiger prawn, Penaeus

92 semisulcatus.

\section{Materials and methods}

\subsection{Sampling and sample preparation}

Fish and prawn samples were caught from along the coastal waters of the Persian Gulf during June

972015 by a trawl net from five locations (see Figure 1), one of which served as a control site (S5;

98 the fishery port of Hendijan located outside the estuary and $70 \mathrm{~km}$ from any petrochemical

99 facilities). At each station, up to five samples of each species were collected, with a total catch of

10056 specimens among all species. Samples were transported in a cooler to the laboratory where they

101 were stored at $-20{ }^{\circ} \mathrm{C}$ pending processing and analysis. 
103 Given the ubiquity of MPs in the indoor environment (Gasperi et al., 2018), suitable measures 104 were undertaken to prevent plastic and fibre contamination in the laboratory. Thus, all chemical 105 reagents were filtered (8- $\mu \mathrm{m}$, Whatman No. 540) before use and white cotton laboratory coats, 106 single-use latex gloves and face masks were used throughout sample manipulation and processing.

107 Working surfaces were thoroughly cleaned with ethanol and all glassware, tools and fish and 108 prawn skin surfaces were washed successively with a commercial dishwashing liquid, HPLC109 grade distilled water and ethanol before being dried in an oven at $105{ }^{\circ} \mathrm{C}$ (glassware and tools) or 110 at room temperature in a metal cabinet (skin surfaces). Analysis of two procedural blanks (without 111 tissues) and distilled water contained in two wide dishes that had been left exposed during the 112 duration of sample processing revealed no contamination from MPs under the working conditions 113 in the laboratory.

\subsection{Extraction of MPs}

116 As required, specimens were thawed and the fork length from the mouth to the central point of the

117 caudal fin and body weight were recorded. Each fish was gutted and dissected in a metal tray using 118 a scalpel, forceps and scissors and the muscle, skin, gills, liver and gut (gastrointestinal tract) 119 retrieved. The pooled livers, guts and gills from each species and at each site were transferred 120 directly to covered petri dishes while pooled muscles and skin, after separation, were homogenized 121 using an Electric Meat Grinder (KENWOOD MG510, UK) before about $15 \mathrm{~g}$ of each was retained 122 and stored in a petri dish. For the (smaller) prawns, tissue retained for analysis was restricted to 123 the muscle and skin (exoskeleton) that was pooled from individuals and homogenized as above. 
125 Tissues of fish and prawn were subject to digestion to remove organic matter and leave behind 126 silica/aluminosilicates and any plastic (Karami et al., 2017). Thus, tissues were emptied into a 127 series of $500 \mathrm{~mL}$ glass beakers to which approximately $30 \mathrm{~mL}$ of $35 \% \mathrm{H}_{2} \mathrm{O}_{2}$ (Arman Sina) and 30 $128 \mathrm{~mL}$ of $4 \% \mathrm{KOH}$ (Merck) were added. The contents were digested for $72 \mathrm{~h}$ at $60{ }^{\circ} \mathrm{C}$ in an oven to 129 dissolve the soft organic components of the tissues, before a 10:40 ml mixture of $68 \% \mathrm{HClO}_{4}$ and $13065 \% \mathrm{HNO}_{3}$ (both Merck) was added to completely digest more resistant material like the gills and 131 skin-exoskeleton. After a few minutes of acid extraction, digests were diluted with warm distilled 132 water to preserve the integrity of MPs. Plastics were separated from all tissues with the exception 133 of the gut by shaking digests at $350 \mathrm{rpm}$ for $5 \mathrm{~min}$ and subsequently centrifuging triplicate aliquots 134 for $5 \mathrm{~min}$ at $4000 \mathrm{rpm}$. Supernatants were directly filtered under vacuum through $\mathrm{S} \& \mathrm{~S}$ grade $135589 / 3$ filters which were subsequently stored and dried (at room temperature) in individual petri 136 dishes pending analysis.

138 For MPs embedded in the gastrointestinal tract of fish, remaining digests were agitated at $350 \mathrm{rpm}$ 139 for $5 \mathrm{~min}$ in a solution of concentrated sodium iodide $\left(\mathrm{NaI}, \mathrm{Merck}\right.$; density $\left.=1.6-1.8 \mathrm{~g} \mathrm{~cm}^{-3}\right)$ to 140 separate plastics from additional material that had been ingested with subsequent filtration and 141 storage undertaken as above.

\subsection{Observation and validation of MPs}

144 A visual assessment of material retained on the filters, and including any arising from the 145 procedural control, was made according to colour, size and morphology (elongated fibre versus 146 angular fragment) and at up to $200 \mathrm{x}$ magnification using a Carl-Zeiss binocular microscope. The

147 presence of plastic was verified by the colours returned by polarized light microscopy using an 
Olympus BX41TF microscope and by fluorescence microscopy using an Olympus CX31 microscope. Images from all microscopic techniques were captured using an Olympus Pen EPL 1

150 digital camera.

151

152 Based on the optical microscopy results, the topography and elemental composition of selected 153 MPs were determined through high vacuum SEM/EDS. We used a Tescan VEGA 3 electron 154 microscope (with a resolution of $2 \mathrm{~nm}$ at $20 \mathrm{kV}$ ) and an Oxford Instruments X-Max 50 silicon drift 155 detector with AZtec and INCA software after samples that had been carefully brushed from the 156 filters were mounted on double-sided adhesive carbon tabs on aluminium SEM stubs.

\section{Results}

\subsection{Size and weight of fish and prawns}

Table 1 summarises the catch from each sampling site (note that the number of species caught at each site varied and that some species were absent from sites 1,2 and 3). Also shown are the mean,

162 minimum and maximum lengths and weights of each of the five species, serving to illustrate 163 differences in size among species and between sites and, for a given species, differences in age 164 and, therefore, propensity to have accumulated MPs.

\subsection{MPs in fish and prawns}

167 Table 2 shows the number of MPs in the tissues of the five species at each site, with data pooled 168 for the number of individuals indicated in Table 1. Note that MPs were detected visually (Figure 169 2), with the synthetic nature of samples confirmed by fluorescence and polarized light 
170 microscopies for characteristic response to visible and ultraviolet light (Woodall et al., 2015; Wang

171 et al., 2016; Figure 3) and, for selected samples, by SEM/EDS for surface morphology and

172 elemental composition (mainly carbon). By comparison, no particles of this nature were observed

173 on the two filters arising from the procedural controls.

174

175 Among the catch, 828 pieces of MP were detected, being encountered across all tissues from each 176 species. In only isolated cases (e.g. the liver of $P$. indicus from sites 1,2 and 5 and the gut of $P$.

177 indicus at site 5) were MPs absent, with numbers exceeding 25 in the skin of S. sihama at site 2,

178 the gills of $P$. indicus at site 4 and the skin of $P$. indicus at site 5. On this basis, there were no clear

179 differences in the total number of MPs accumulated by each species or between sites (and 180 including the control site), but numbers tended to be higher in the skin, muscle and gills than the 181 gut and liver of S. sihama and P. indicus and were always greater in the skin than in muscle from $182 P$. semisulcatus. When considered on an individual basis, or after total numbers for each species 183 had been normalized for the number of samples analysed, MPs are most abundant in $P$. indicus 184 (mean $=21.8)$ and least frequently encountered in P. semisulcatus $($ mean $=7.8)$; when normalized 185 on a mass basis, however, the mean abundance of MPs ranged from $0.16 \mathrm{~g}^{-1}$ for C. abbreviatus to $1861.5 \mathrm{~g}^{-1}$ for P. semisulcatus. By comparison, a recent study by Akhbarizadeh et al. (2018) in the 187 northeast of the Persian Gulf reports an average abundance of MPs in muscle of the fish, P. indicus, 188 Sphyraena jello and Epinephelus voioides, and the shrimp, Alepes djedaba, of $1.85 \pm 0.46,0.57 \pm$ $1890.17,0.78 \pm 0.22$ and $0.80 \pm 0.12 \mathrm{~g}^{-1}$, respectively.

191 Nearly all MPs encountered were filamentous fragments (consisting of single fibres) of different 192 size and colour and as illustrated in Figure 2. In only five cases were non-fibrous plastics found 
193 among the different species of fish: specifically, two white fragments in the muscle of $C$. 194 abbreviatus from site 5, one yellow fragment in the gills of S. sihama from site 4 and one blue 195 fragment in the gastrointestinal tract of both S. sihama at site 4 and $S$. tumbil at site 1.

197 The size distributions of MPs are shown in Table 3 for individual tissues and in Figure 4 for whole 198 organisms. Thus, there is a wide range of lengths of (mainly) filamentous material across all 199 species, with the most abundant sizes between either 100 and $250 \mu \mathrm{m}$ (S. sihama, P. indicus, P. 200 semisulcatus) or 250 to $500 \mu \mathrm{m}$ (C. abbreviatus, S. tumbil). With respect to the different tissue 201 types, the digestive organs appear to contain a high proportion of relatively large MPs, while 202 particles above $250 \mu \mathrm{m}$ are absent from the liver.

204 The colour distribution of the MPs that had visibly accumulated is shown in Figure 5. Thus, 205 overall, $71 \%$ of MPs consisted of black or grey filamentous fragments, with blue and green 206 fragments comprising about $12 \%$ of the MP pool. White-transparent and red-pink fragments 207 contributed about 7 and 8\%, respectively, with yellow-orange material lowest in overall abundance 208 at about $1.3 \%$. There were no clear differences in colours accumulated by different species or in 209 different organs. However, there were notable differences in the distribution of certain colours 210 between the different sites; for instance, only one white-transparent fragment and no yellow211 orange fragments were recorded at site 1 while six yellow-orange and 20 white-transparent 212 fragments were observed at sites 4 and 5, respectively.

214 In addition to the MPs described above and quantified in Tables 2 and 3, a number of fragmented 215 particles of between a few tens of nm to a few hundred $\mu \mathrm{m}$ in diameter were observed in the guts 
216 and gills of (mainly) pelagic fish that were distinctly different. Thus, EDS revealed the presence

217 of metals, and mainly $\mathrm{Cu}$, in addition to $\mathrm{C}$ and $\mathrm{O}$, while manipulation during analysis and SEM

218 imagery showed that the material was highly brittle (Figure 6). It is possible that these particles

219 were of metal construction, at least in part. However, given the detection of both organic material

220 and $\mathrm{Cu}$, we suspect that these particles are small flakes of paint impregnated with $\mathrm{Cu}$. Most

221 contemporary antifouling paint formulations employ $\mathrm{Cu}$ as a biocide and are generated abundantly

222 at boat maintenance and repair facilities and are also shed from boat hulls and other painted

223 maritime structures while in use (Turner, 2010).

224

225 4. Discussion

226 This study is one of an emerging number demonstrating the accumulation of MPs by marine 227 organisms. Of the MPs detected, and consistent with previous environmental studies, they are 228 mainly fibrous (Lusher et al., 2013; Rochman et al., 2015; Pazos et al., 2017), with sizes ranging 229 from $<100 \mu \mathrm{m}$ to $>1000 \mu \mathrm{m}$. MPs are generally larger in the gills and gastrointestinal tract than 230 in other organs because larger material can readily enter the digestive environment with relatively 231 little obstruction; the abundance of MPs in the digestive environment is also rather variable, 232 reflecting variations in the amount and type of consumed food both between individuals of the 233 same species and among different species.

235 Despite some planktivorous fish seeming to select MPs that are visually similar to their diet (i.e. 236 blue fragments) (Ory et al., 2017), without information on the colour distribution of MPs in the 237 water column or sediments of the Musa estuary and Persian Gulf there is no evidence in the present 238 study for the preferential ingestion or accumulation of MPs according to appearance. We also do 
239 not have specific information on the type of plastics found in the organisms sampled, although

240 MPs retrieved from littoral sediments of the Persian Gulf indicate a predominance of polyethylene,

241 nylon and polyethylene terephthalate (Naji et al., 2017).

243 On an individual basis, MP abundance ranges from about 8 for the prawn, $P$. semisulcatus, to over 24420 for the demersal fish, $P$. indicus, that forages in the sediment and where most of the denser MPs 245 reside. These values are higher than those reported for fish in previous studies; for example, up to 2467.2 items per individual were observed in coastal and freshwater fish from China (Jabeen et al., 247 2017), up to about 4 per individual were detected in the semi-pelagic Mediterranean fish, Boops 248 boops (L.). (Nadal et al., 2016), and an average of 1.6 items per fish were recorded in various 249 demersal fish in Spanish coastal waters (Bellas et al., 2016). However, it is important to appreciate 250 that these studies focused on the retrieval of MPs from the digestive tract only. When our data are 251 restricted to the gut, the average number of MPs per individual ranges from about 1.5 in S. sihama 252 to 3 in C. abbreviatus (see Table 2).

254 The discrepancies referred to above arise from the general assumption that accumulation of plastics 255 by fish and other organisms proceeds mainly through ingestion and is, therefore, dependent on 256 factors like feeding strategy and gut structure as well as the extent of local plastic pollution (Romeo 257 et al., 2015; Jabeen et al., 2017). Thus, MPs may be accumulated directly and incidentally or 258 deliberately while feeding from the water column or sifting through contaminated sediment, or 259 indirectly through the consumption of contaminated prey (Cannon et al., 2016; Jovanović, 2017). 260 The detection of MPs in the present study in organs not directly involved with ingestion-digestion 
261 suggests that other factors may be significant for the accumulation and, potentially, translocation 262 of MPs in fish.

264 Results of laboratory experiments have reported the occurrence of MPs in the circulatory system 265 or non-digestive organs of marine invertebrates (Browne et al., 2008; von Moos et al., 2012) and 266 in the liver of zebrafish (Lu et al., 2016). However, particles employed in these studies were on 267 the order of tens of micrometers in diameter or less, thereby facilitating passage across the gill or 268 gut epithelium through cell internalization and subsequent translocation. Collard et al. (2017) 269 suggest that detection of larger MPs (and of dimensions comparable to those observed here) in the 270 livers of European anchovies (Engraulis encrasicolus) may result from two processes: the 271 agglomeration of smaller particles and/or passage through the gut barrier by some form of 272 intracellular or paracellular endocytosis. The former mechanism is unlikely in the present study 273 because SEM images revealed distinct and relatively smooth fibrous fragments, and without 274 knowledge of the locations of MPs in (homogenized) tissue the latter mechanism cannot be fully 275 explained.

277 Alternatively, it has recently been suggested that adherence affords an additional means by which 278 fibrous MPs may associate with organs independent of the digestive system, in a manner by which 279 seaweeds accumulate plastics (Gutow et al., 2016). Thus, under laboratory conditions, about 50\% 280 of microfibres exceeding $100 \mu \mathrm{m}$ in marine mussels could be accounted for through adherence, 281 with surface area and "stickiness" two important controls in this respect (Kolandhasamy et al., 282 2018). Regardless of the mechanisms by which MPs enter or associate with non-digestive tissues, 283 their occurrence has a number of implications for evaluating the inventory, location and toxicity 
284 of MPs in marine animals, as well as for human health through seafood consumption. Specifically,

285 if the gut is considered as the sole receptacle, where MPs may either be in transit or entrapped, the

286 total number of MPs accumulated by an individual may be considerably underestimated. With

287 respect to toxicity, accumulation outside the digestive tract may induce histological changes and

288 oxidative stress (Lu et al., 2016) or release contaminants associated with or adsorbed to MPs

289 (Ashton et al., 2010). The potential for MPs to be transferred to humans should not be

290 underestimated given that the soft tissue of the species considered are important to the regional

291 fishing industry. According to the Institute of Standards and Industrial Research of Iran in 2010,

292 daily average fish muscle consumption is about $7 \mathrm{~g} /$ person/day, meaning that about 5 MPs could

293 be consumed on a daily basis. While there is currently no regulatory framework concerning the

294 presence of MPs in sea food (European Food Safety Authority 2016), this does not exclude the

295 possibility that MPs are able to interact with human cells and tissues and facilitate the delivery of

296 harmful contaminants to the bloodstream (Santillo et al., 2017).

297

298 5. Conclusions

299 This study has demonstrated the presence of MPs of mainly a fibrous nature and of length $<100$

$300 \mu \mathrm{m}$ to $>1000 \mu \mathrm{m}$ in various commercially important species of fish and a crustacean collected

301 from the Musa estuary and the Persian Gulf. Average quantities of MPs ranged from $0.16 \mathrm{~g}^{-1}$ for

302 the mesopelagic fish, C. abbreviatus, to $1.5 \mathrm{~g}^{-1}$ for the prawn, P. semisulcatus, with particles

303 encountered in various tissues from both digestive and non-digestive organs across all species. The

304 occurrence of MPs outside the digestive system suggests that material can be translocated

305 following ingestion or that additional, non-ingestive mechanisms (e.g. adherence) are significant. 
The presence of MPs in non-digestive organs has the potential to induce toxic effects on individuals and affords an exposure route to humans who consume contaminated fish.

\section{Acknowledgements}

The authors wish to express their gratitude to the Research Committee and Medical Geology Center of Shiraz University for logistical and technical assistance.

\section{References}

- Abbasi, Sajjad., Keshavarzi, Behnam., Moore, Farid., Delshab, Hossein., Soltani, Naghmeh., Sorooshian, Armin., 2017. Investigation of microrubbers, microplastics and heavy metals in street dust: A study in Bushehr city, Iran. Environmental Earth Sciences. DOI: $10.1007 / \mathrm{s} 12665-017-7137-0$.

- Akhbarizadeh, R., Moore, F., Keshavarzi, B., 2018. Investigating a probable relationship between microplastics and potentially toxic elements in fish muscles from northeast of Persian Gulf. Environmental Pollution 232, 154-163.

- Alomar, C., Estarellas, F., Deudero, S., 2016. Microplastics in the Mediterranean Sea: Deposition in coastal shallow sediments, spatial variation and preferential grain size. Marine Environmental Research 115, 1-10.

- Andrady, A.L., 2011. Microplastics in the Marine Environment. Marine Pollution Bulletin 62 1596-1605.

- Ashton, K., Holmes, L., Turner, A., 2010. Association of metals with plastic production pellets in the marine environment. Marine Pollution Bulletin 60, 2050-2055. 
- Auta, H.S., Emenike, C.., Fauziah, S.., 2017. Distribution and importance of microplastics in the marine environment: A review of the sources, fate, effects, and potential solutions. Environment International 102, 165-176.

- Barnes, D.K.A., Galgani, F., Thompson, R.C., Barlaz, M., 2009. Accumulation and fragmentation of plastic debris in global environments. Philosophical Transactions of the Royal Society of London B: Biological Sciences 364, 1985-1998.

- Bellas, J., Martinez-Armental, J., Martinez-Camara, A., Beseda, V., Martinez-Gómez, C., 2016. Ingestion of microplastics by demersal fish from the Spanish Atlantic and Mediterranean coasts. Marine Pollution Bulletin 109, 55-60.

- Browne, M.A., Dissanayake, A., Galloway, T.S., Lowe, D.M., Thompson, R.C., 2008. Ingested microscopic plastic translocates to the circulatory system of the mussel, Mytilus edulis (L.). Environmental Science and Technology 42, 5026-5031.

- Cannon, S.M.E., Lavers, J.L., Figueiredo, B., 2016. Plastic ingestion by fish in the Southern Hemisphere: A baseline study and review of methods. Marine Pollution Bulletin $107,286-291$.

- Cole, M., Lindeque, P., Fileman, E., Halsband, C., Goodhead, R., Moger, J., Galloway, T.S., 2013. Microplastic ingestion by zooplankton. Environmental Science and Technology 47, 6646-6655.

- Collard, F., Gilbert, B., Compère, P., Eppe, G., Das, K., Jauniaux, T., Parmentier, E., 2017. Microplastics in livers of European anchovies (Engraulis encrasicolus , L.). Environmental Pollution 229, 1000-1005.

- De Sá, L.C., Luís, G.L., Guilhermino, L., 2015. Effects of microplastics on juveniles of the common goby (Pomatoschistus microps): confusion with prey, reduction of the predatory 
performance and efficiency, and possible influence of developmental conditions. Environmental Pollution 196, 359-362.

- do Sul, J.A.I., Costa, M.F., 2014. The present and future of microplastic pollution in the marine environment. Environmental Pollution 185, 352-364.

- European Food Safety Authority, 2016. Presence of microplastics and nanoplastics in food, with particular focus on seafood. EFSA Journal 14, 4501 (30 pp).

- Ferreira, P., Fonte, E., Soares, M.E., Carvalho, F., Guilhermino, L., 2016. Effects of multistressors on juveniles of the marine fish Pomatoschistus microps: gold nanoparticles, microplastics and temperature. Aquatic Toxicology 170, 89-103.

- Gasperi, J., Wright, S.L., Dris, R., Collard, F., Mandin, C., Guerrouache, M., Langlois, V., Kelly, F.J., Tassin, B., 2018. Microplastics in air: Are we breathing it in? Current Opinion in Environmental Science \& Health 1, 1-5.

- Gutow, L., Eckerlebe, A., Gimenez, L., Saborowski, R., 2016. Experimental evaluation of seaweeds as a vector for microplastics into marine food webs. Environmental Science and Technology 50, 915-923.

- Hidalgo-Ruz, V., Gutow, L., Thompson, R.C., Thiel, M., 2012. Microplastics in the marine environment: A review of the methods used for identification and quantification. Environmental Science and Technology 46, 3060-3075.

- Holmes, L.A., Turner, A., Thompson, R.C., 2014. Interactions between trace metals and plastic production pellets under estuarine conditions. Marine Chemistry 167, 25-32.

- Hosseini, M., Nabavi, S.M.B., Mansoori, A., Saadatmant, M., 2013. Mercury Levels in Selected Tissues of Blue Crab Thalamita prymna (Portunidae) from Musa Estuary of the Persian Gulf. Journal of the Persian Gulf 4, 33-38. 
- Jabeen, K., Su, L., Li, J.N., Yang, D.Q., Tong, C.F., Mu, J.L., Shi, H.H., 2017. Microplastics and mesoplastics in fish from coastal and fresh waters of China. Environmental Pollution 221, 141-149.

- Jambeck, J.R., Geyer, R., Wilcox, C., Siegler, T.R., Perryman, M., Andrady, A., Narayan, R., Law, K.L., 2015. Plastic waste inputs from land into the ocean. Science 347, 768-771. - Jovanović, B., Ingestion of microplastics by fish and its potential consequences from a physical perspective. Integrated Environmental Assessment and Management 13, 510-515.

- Kolandhasamy, P., Su, L., Li, J., Qu, X., Jabeen, K., Shi, H., 2018. Adherence of microplastics to soft tissue of mussels: A novel way to uptake microplastics beyond ingestion. Science of the Total Environment 610-611, 635-640.

- Li, J., Yang, D., Li, L., Jabeen, K., Shi, H., 2015. Microplastics in commercial bivalves from China. Environmental Pollution 207, 190-195.

- Lu, Y., Zhang, Y., Deng, Y., Jiang, W., Zhao, Y., Geng, J., Ding, L., Ren, H., 2016. Uptake and Accumulation of Polystyrene Microplastics in Zebrafish (Danio rerio) and Toxic Effects in Liver. Environmental Science \& Technology 50, 4054-4060.

- Luís, L.G., Ferreira, P., Fonte, E., Oliveira, M., Guilhermino, L., 2015. Does the presence of microplastics influence the acute toxicity of chromium (VI) to early juveniles of the common goby (Pomatoschistus microps)? A study with juveniles from two wild estuarine populations. Aquatic Toxicology 164, 163-74.

- Lusher, A., McHugh, M., Thompson, R.C., 2013. Occurrence of microplastics in the gastrointestinal tract of pelagic and demersal fish from the English Channel. Marine Pollution Bulletin 67, 94-99. 
- Lusher, A.L, Tirelli, V., O’Connor, I., Officer, R., 2015. Microplastics in Arctic polar waters: The first reported values of particles in surface and sub-surface samples. Scientific Reports 5, 14947

- Moore, C.J., 2008. Synthetic polymers in the marine environment: a rapidly increasing, long-term threat. Environmental Research 108, 131-139.

- Nadal, M.A., Alomar, C., Deudero, S., 2016. High levels of microplastic ingestion by the semipelagic fish bogue Boops boops (L.) around the Balearic Islands. Environmental Pollution 214, 517-23.

- Naji, A., Esmaili, Z., Khan, F.R., 2017. Plastic debris and microplastics along the beaches 405 of the Strait of Hormuz, Persian Gulf. Marine Pollution Bulletin 114, 1057-1062.

- Ory, N.C., Sobral, P., Ferreira, J.L., Thiel, M., 2017. Amberstripe scad Decapterus muroadsi (Carangidae) fish ingest blue microplastics resembling their copepod prey along the coast of Rapa Nui (Easter Island) in the South Pacific subtropical gyre. Science of the Total Environment 586, 430-437.

- Pazos, R.S., Maiztegui, T., Colautti, D.C., Paracampo, A.H., Gómez, N., 2017. Microplastics in gut contents of coastal freshwater fish from Rio de la Plata estuary. Marine Pollution Bulletin 122, 85-90.

- Rastegari Mehr, M., Keshavarzi, B., Moore, F., Sacchi, E., Lahijanzadeh, A.R., Eydivand, S., Jaafarzadeh, N., Naserian, S., Setti, M., Rostami, S., 2016. Contamination level and human health hazard assessment of heavy metals and polycyclic aromatic hydrocarbons (PAHs) in street dust deposited in Mahshahr, southwest of Iran. Human and Ecological Risk Assessment: An International Journal 22, 1726-1748. 
- Rist, S., Almroth, B.C., Hartmann, N.B., Karlsson, T.M., 2018. A critical perspective on early communications concerning human health aspects of microplastics. Science of The Total Environment 626, 720-726.

- Rochman, C.M., Tahir, A., Williams, S.L., Baxa, D.V., Lam, R., Miller, J.T., Teh, F.C., Werorilangi, S., Teh, S.J., 2015. Anthropogenic debris in seafood: plastic debris and fibers from textiles in fish and bivalves sold for human consumption. Scientific Reports. 5, 14340.

- Romeo, T., Pietro, B., Peda, C., Consoli, P., Andaloro, F., Fossi, M.C., 2015. First evidence 425

426 of presence of plastic debris in stomach of large pelagic fish in the Mediterranean Sea. Marine Pollution Bulletin 95, 358-361.

- Santillo, D., Miller, K., Johnston, P., 2017. Microplastics as contaminants in commercially important seafood species. Integrated Environmental Assessment and Management 13, 516-521.

- Teuten, E.L., Rowland, S.J., Galloway, T.S., Thompson, R.S., 2007. Potential for plastics to transport hydrophobic contaminants. Environmental Science and Technology 41, 77597764.

- Turner, A., 2010. Marine pollution from antifouling paint particles. Marine Pollution Bulletin 60, 159-171.

- Turner, A., 2017. In situ elemental characterisation of marine microplastics by portable XRF. Marine Pollution Bulletin 124, 286-291.

- Van Cauwenberghe, L., Janssen, C.R., 2014. Microplastics in bivalves cultured for human consumption. Environmental Pollution 193, 65-70. 
457 Figure captions:

458

459

460

461 462 1667-1676.

- Van Cauwenberghe, L., Claessens, M., Vandegehuchte, M.B., Janssen, C.R., 2015. Microplastics are taken up by mussels (Mytilus edulis) and lugworms (Arenicola marina) living in natural habitats. Environmental Pollution 199, 10-17.

- von Moos, N., Burkhardt-Holm, P., Koehler, A., 2012. Uptake and effects of microplastics on cells and tissue of the blue mussel Mytilus edulis L. after an experimental exposure. Environmental Science and Technology 46, 11327-11335.

- Wang, J., Tan, Z., Peng, J., Qiu, Q., Li, M., 2016. The behaviors of microplastics in the marine environment. Marine Environmental Research 113, 7-17.

- Woodall, L.C., Gwinnett, C., Packer, M., Thompson, R.C., Robinson, L.F., Paterson, G.L.J., 2015. Using a forensic science approach to minimize environmental contamination and to identify microfibres in marine sediments. Marine Pollution Bulletin 95, 40-46.

- Wright, S.L., Thompson, R.C., Galloway, T.S., 2013. The physical impacts of microplastics on marine organisms: A review. Environmental Pollution 178, 483-492.

- Ziccardi, L.M., Edgington, A., Hentz, K., Kulacki, K.J., Driscoll, S.K., 2016. Microplastics as vectors for bioaccumulation of hydrophobic organic chemicals in the marine environment: a state-of-the-science review. Environmental Toxicology and Chemistry 35,

Figure 1: Locations of the five sampling sites along the coast of the Musa estuary.

Figure 2: Examples of MPs encountered in fish and prawn tissues and as captured by binocular microscope. Note that fibres in panels (b) and (g) are extremely thin and, therefore, have a relatively high propensity to penetrate tissue, and that fibres in panels (c), (d), (f), (h), (i) and (j) exhibit partial entrapment in half-digested tissues. 
463 Figure 3: An image and the composition of a fibre obtained by SEM/EDS (W\% = weight percent 464 and $\mathrm{A} \%=$ atomic percent) (a); fibre images obtained using upper-light fluorescence microscopy 465 (b,c); fibre images obtained by polarized downward projecting light microscopy (e,g) and 466 corresponding images obtained without polarized light $(\mathrm{d}, \mathrm{f})$.

467 Figure 4: The net distribution of MPs among different size categories (in $\mu \mathrm{m}$ ) in the five species. 468 Figure 5: Overall colour distribution of the MPs observed in the samples.

469 Figure 6: SEM/EDS image and composition of a particle of a relatively brittle and non-fibrous 470 natu

471 
472 Table 1: Number of species caught from each site $(n)$ together with the mean (and minimum and 473 maximum) lengths $(\mathrm{cm})$ and weights $(\mathrm{g})$.

\begin{tabular}{|c|c|c|c|c|c|c|}
\hline & & S. sihama & $P$. indicus & C. abbreviatus & S. tumbil & p. semisulcatus \\
\hline \multirow[t]{3}{*}{ S1 } & $n$ & 4 & 3 & 4 & & \\
\hline & length & $20.1(17.2-20.1)$ & $17.3(16.5-18.5)$ & $17.7(14.2-20.5)$ & & \\
\hline & weight & $67.8(49.3-95.1)$ & $23.8(18.3-32.7)$ & $33.1(14.2-56.6)$ & & \\
\hline \multirow[t]{3}{*}{ S2 } & $n$ & 4 & 1 & 4 & & \\
\hline & length & $16.6(13.0-20.0)$ & 16.0 & $17.7(14.2-20.5)$ & & \\
\hline & weight & $39.4(14.2-62.4)$ & 16.8 & $33.1(14.2-56.6)$ & & \\
\hline \multirow[t]{3}{*}{ S3 } & $n$ & & & & & 5 \\
\hline & length & & & & & $7.8(5.5-10.0)$ \\
\hline & weight & & & & & $5.4(2.3-10.6)$ \\
\hline \multirow[t]{3}{*}{ S4 } & $n$ & 4 & 4 & 3 & 4 & 3 \\
\hline & length & $16.6(15.5-18.0)$ & $19.5(18.5-21.5)$ & $23.7(23.0-24.0)$ & $15.7(13.0-18.0)$ & $7.3(6.0-8.5)$ \\
\hline & weight & $45.6(36.4-53.3)$ & $46.7(35.7-63.6)$ & $115.9(109.3-123.0)$ & $36.1(18.6-50.4)$ & $5.2(2.5-8.0)$ \\
\hline \multirow[t]{3}{*}{ S5 } & $n$ & 5 & 4 & 4 & & 4 \\
\hline & length & $20.5(18.5-24.5)$ & $20.5(20.0-22.0)$ & $23.8(22.5-26.0)$ & & $7.6(4.5-10.5)$ \\
\hline & weight & $72.2(51.8-119.9)$ & $41.7(39.1-46.5)$ & $88.4(75.2-115.4)$ & & $4.9(1.4-8.7)$ \\
\hline \multirow[t]{3}{*}{ total } & $n$ & 17 & 12 & 15 & 4 & 12 \\
\hline & length & $18.6(13.0-24.5)$ & $19.0(16.0-22.0)$ & $24.6(14.2-21.7)$ & $15.7(13.0-18.0)$ & $7.6(4.5-10.5)$ \\
\hline & weight & $57.2(14.2-119.9)$ & $36.8(16.8-63.6)$ & $75.8(14.2-123.0)$ & $36.1(18.6-50.4)$ & $5.2(1.4-10.6)$ \\
\hline
\end{tabular}

475

476

477

478

479 
480 Table 2: Number of MPs detected in the five species pooled from each site (with the number of 481 species given in Table 1). Also shown is the total number of MPs in each species, the mean number 482 when normalized for the number of individuals analysed and the average mass of individuals, and 483 the mean number per individual when only the gut was considered.

\begin{tabular}{|c|c|c|c|c|c|c|}
\hline & & S. sihama & P. indicus & C. abbreviatus & S. tumbil & P. semisulcatus \\
\hline \multirow[t]{5}{*}{ S1 } & skin & 7 & 27 & & & \\
\hline & muscle & 14 & 7 & & & \\
\hline & gut & 1 & 11 & & & \\
\hline & gills & 15 & 22 & & & \\
\hline & liver & 6 & 0 & & & \\
\hline \multirow[t]{5}{*}{ S2 } & skin & 29 & 14 & 8 & & \\
\hline & muscle & 20 & 21 & 10 & & \\
\hline & gut & 9 & 4 & 11 & & \\
\hline & gills & 12 & 12 & 12 & & \\
\hline & liver & 4 & 0 & 5 & & \\
\hline \multirow[t]{5}{*}{ S3 } & skin & & & & & 23 \\
\hline & muscle & & & & & 12 \\
\hline & gut & & & & & \\
\hline & gills & & & & & \\
\hline & liver & & & & & \\
\hline \multirow[t]{5}{*}{ S4 } & skin & 14 & 14 & 8 & 6 & 21 \\
\hline & muscle & 19 & 14 & 12 & 12 & 14 \\
\hline & gut & 12 & 12 & 18 & 11 & \\
\hline & gills & 20 & 27 & 13 & 8 & \\
\hline & liver & 11 & 13 & 24 & 17 & \\
\hline \multirow[t]{5}{*}{ S5 } & skin & 11 & 27 & 13 & & 14 \\
\hline & muscle & 11 & 13 & 12 & & 10 \\
\hline & gut & 4 & 0 & 15 & & \\
\hline & gills & 8 & 23 & 8 & & \\
\hline & liver & 12 & 0 & 11 & & \\
\hline total & & 239 & 261 & 180 & 54 & 94 \\
\hline mean/individual & & 14.1 & 21.8 & 12.0 & 13.5 & 7.8 \\
\hline mean/g & & 0.25 & 0.59 & 0.16 & 0.37 & 1.51 \\
\hline mean/gut & & 1.5 & 2.3 & 2.9 & 2.8 & \\
\hline
\end{tabular}


$487 \quad$ Fig 1.

488

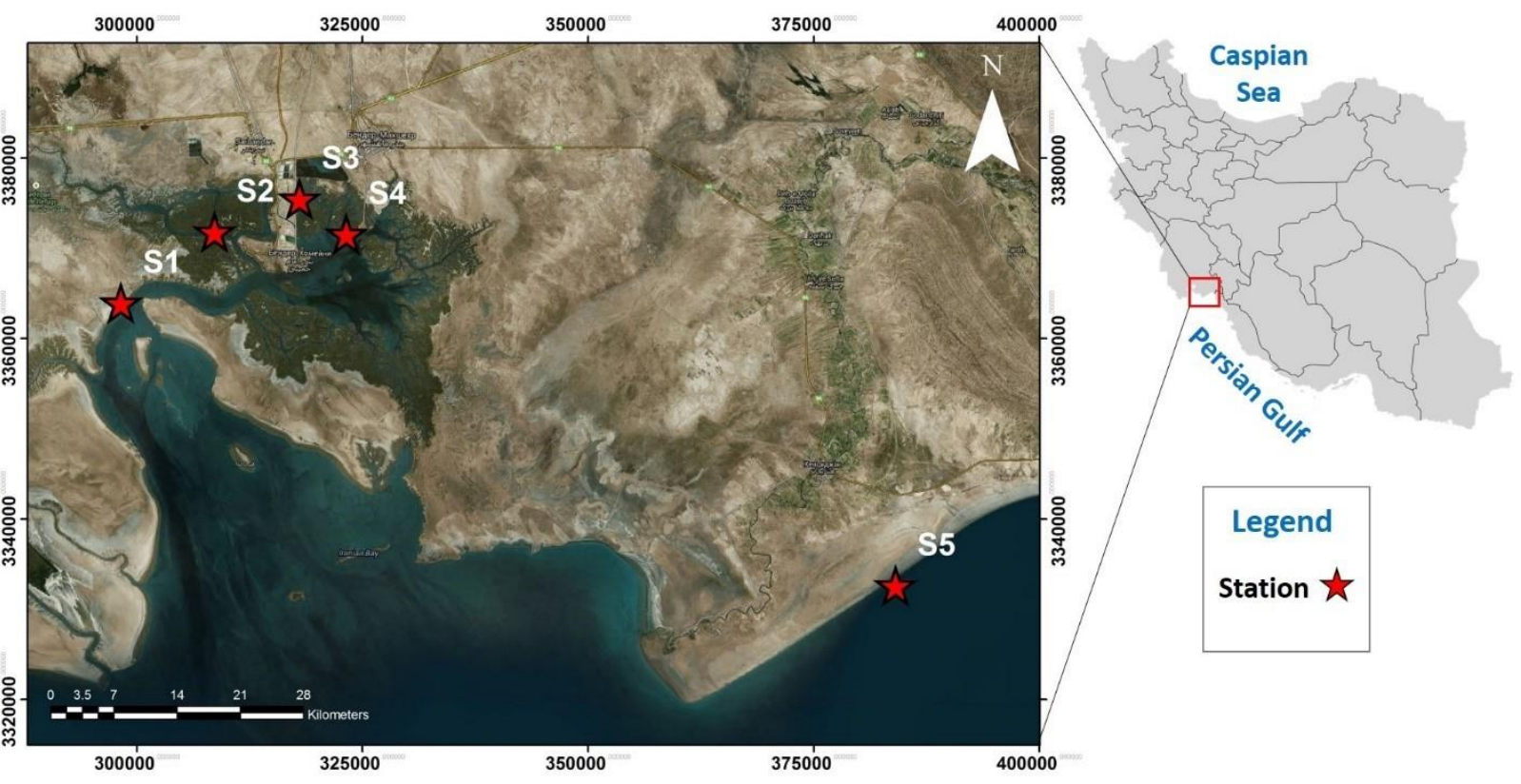

490

491

492

493

494 
$495 \quad$ Fig 2

496

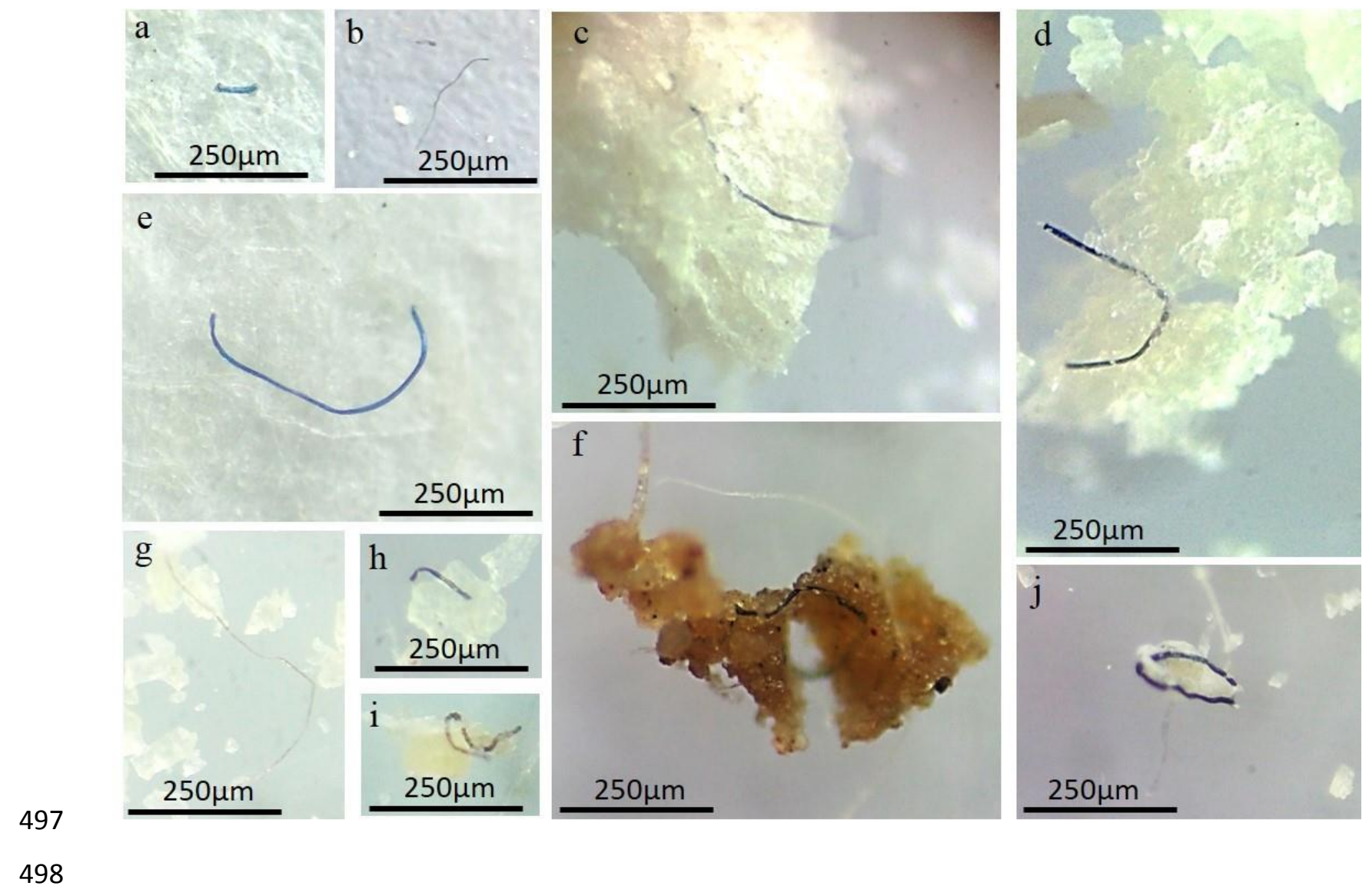


$499 \quad$ Fig 3

500

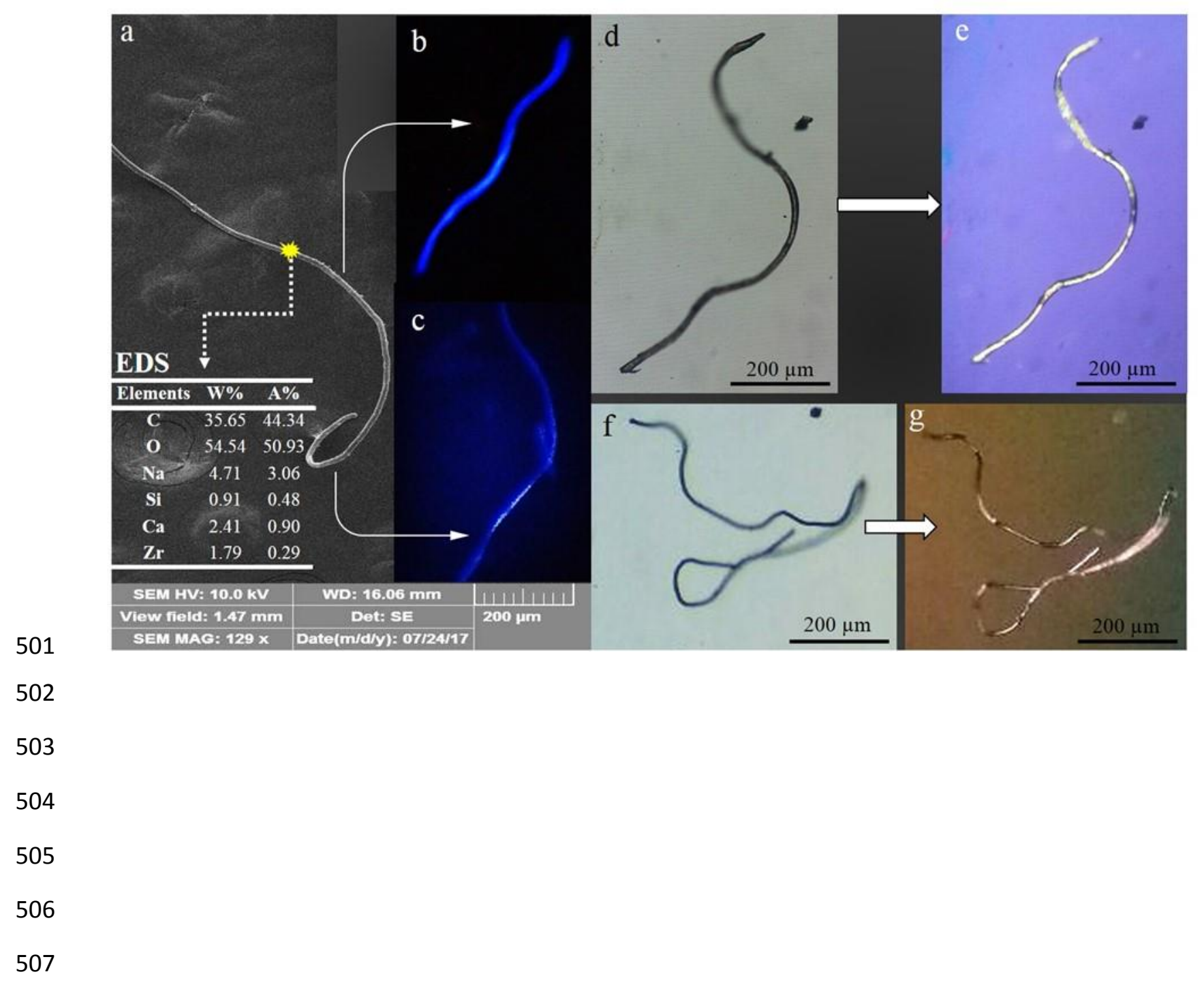


Fig 4
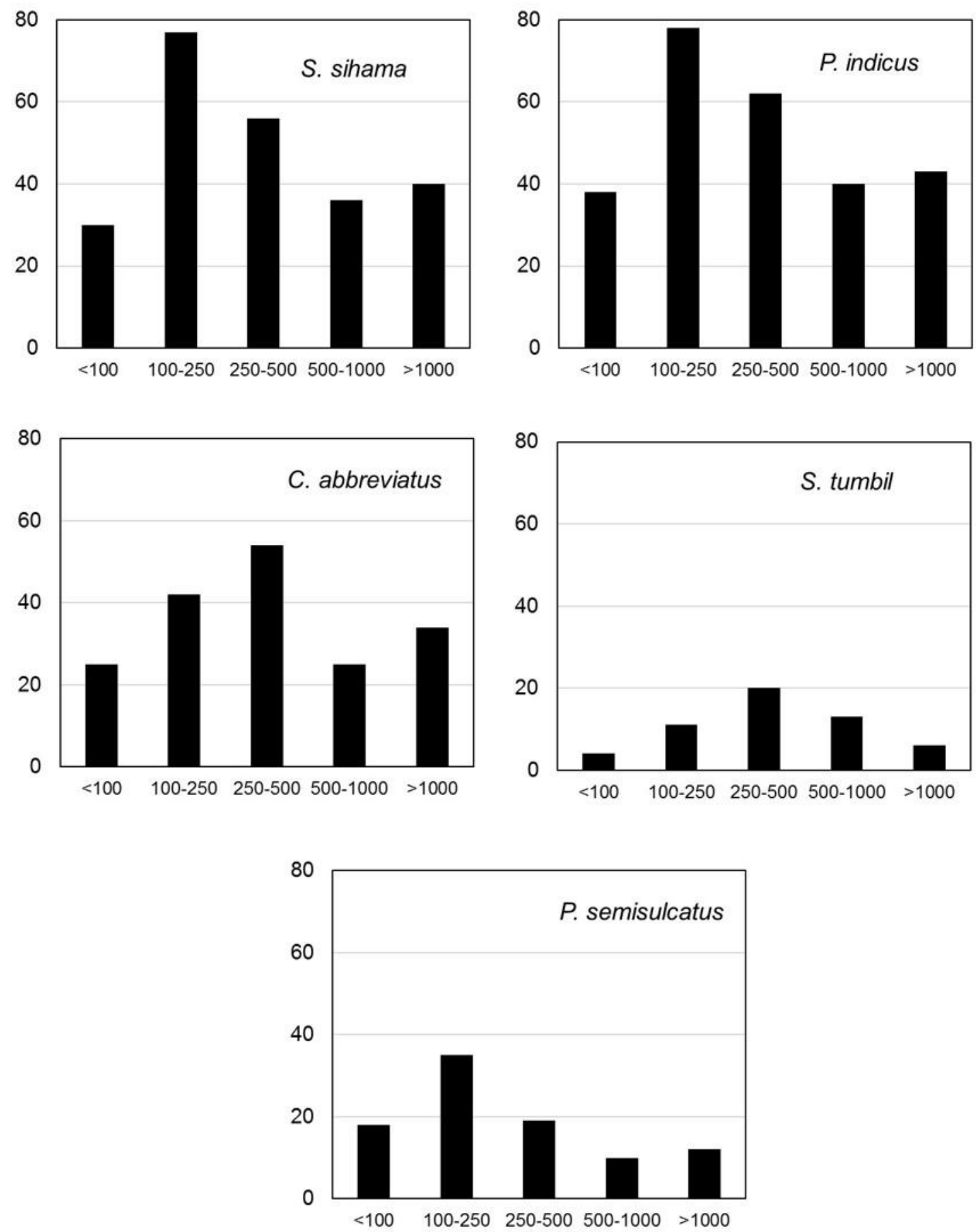
$512 \quad$ Fig 5

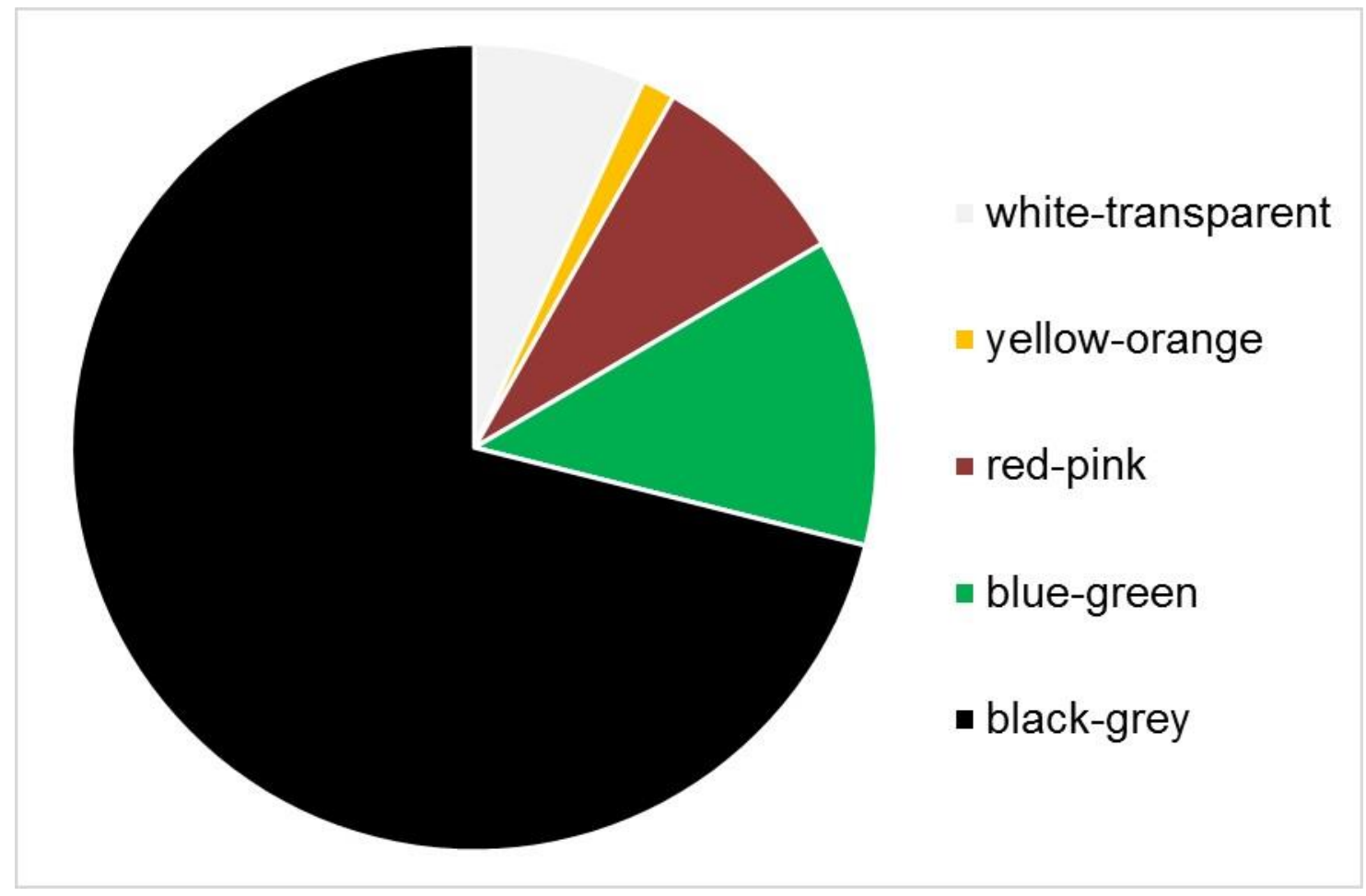

513

514 
$515 \quad$ Fig 6

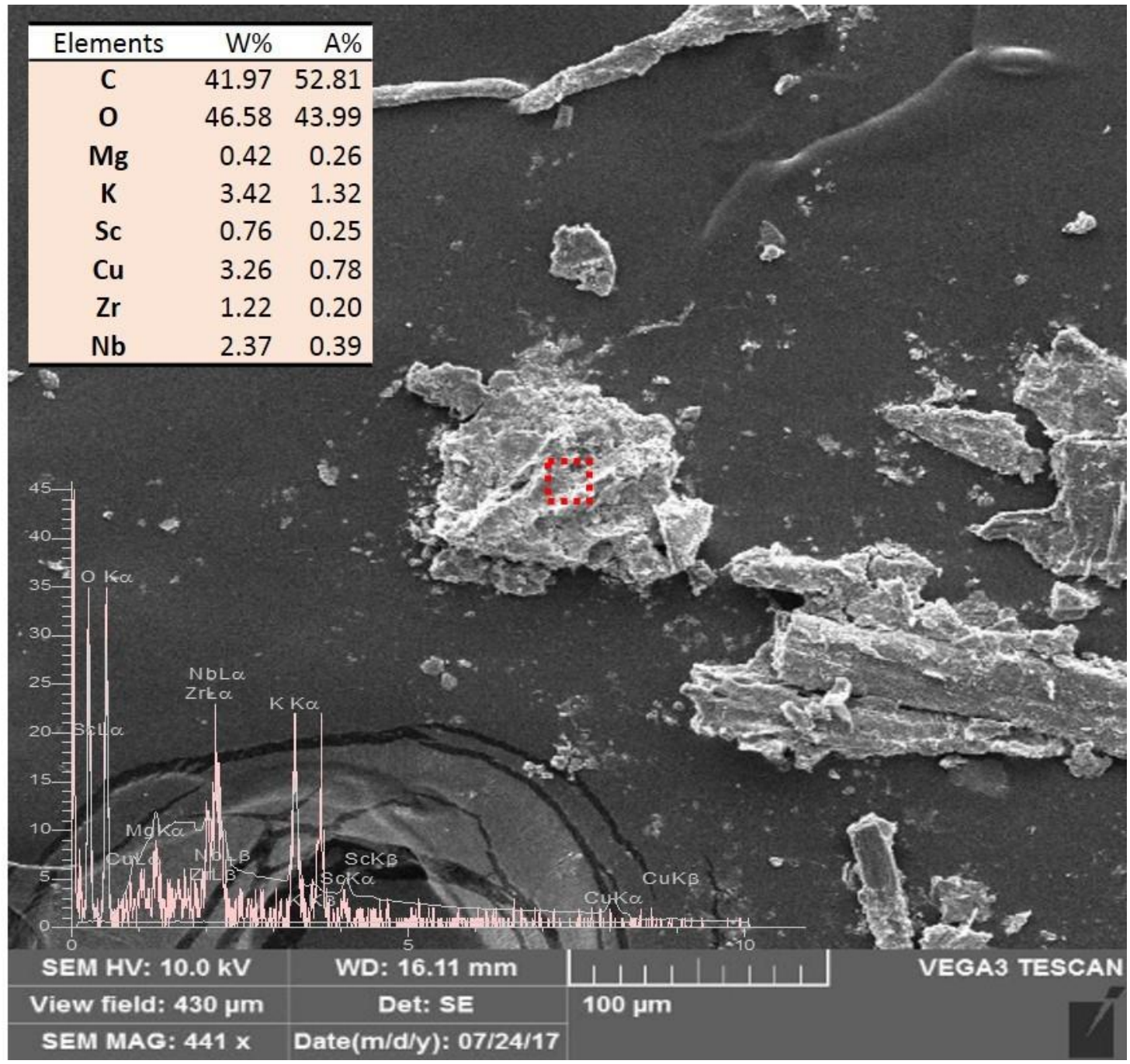

517 
519 re $(\mathrm{W} \%=$ weight percent and $\mathrm{A} \%=$ atomic percent $)$. 